\title{
Ethnobotanical and nutritional study of quelites sold in two traditional
} markets of Oaxaca, Mexico

G.I. Manzanero-Medina ${ }^{1}$, A. Pérez-Herrera ${ }^{1,2, *}$, H. Lustre-Sánchez ${ }^{1}$, M.A. VásquezDávila $^{3}$, N.F. Santos-Sánchez ${ }^{4}$, M.A. Sánchez-Medina ${ }^{5}$

*Author for correspondence: aperezhe@conacyt.mx; tel: (+5219510052951) $(+5219515170610$ ext. 82786)

${ }^{1}$ Instituto Politécnico Nacional-Centro Interdisciplinario de Investigación para el Desarrollo Integral Regional- (CIIDIR) Oaxaca Unit. Hornos Av.,1003, Noche Buena, Santa Cruz Xoxocotlán, 71230, Oaxaca, Mexico. MMGI: manzanerogladys70@gmail.com; LSH: lustre.hls@gmail.com

${ }^{2}$ Consejo Nacional de Ciencia y Tecnología (CONACYT). Insurgentes Sur Av., 1582, Crédito Constructor. Benito Juárez D., 03940, Mexico City, Mexico.

3Instituto Tecnológico del Valle de Oaxaca. Former Hacienda de Nazareno w / n. 71230 Santa Cruz Xoxocotlán. Oaxaca, Mexico VDMA: vasquezdavila2014@gmail.com

${ }^{4}$ Instituto de Agroindustrias, Universidad Tecnológica de la Mixteca. Road to Huajuapan-Acatlima km 2.5, Huajuapan de León, Oaxaca 69000, Mexico. SSNF: nsantos@mixteco.utm.mx

${ }^{5}$ Departamento de Ingeniería Química y Bioquímica, Instituto Tecnológico de Oaxaca. Ing. Víctor Bravo Ahuja Av., 125, corner on Technological Av., 68030, Oaxaca, Mexico. SMMA: mmedinaito@gmail.com 

$47 \quad(p>0.05)$

\section{SUMMARY}

Background. In Mexico, it is called quelites to certain edible vegetables (young plants, germ, shoots or flowers). Since pre-Hispanic times, quelites have been eaten as a source of vitamins, minerals and proteins. Now, its traditional and healthy consumption has decreased. We studied the quelites of two traditional markets in the Valles Centrales of Oaxaca state, Mexico using an ethnobotanical and nutritional approach.

Methods. From July 2017 to July 2018, weekly ethnobotanical interviews were conducted with 26 collectors-sellers of the Zimatlán market and 36 in the Zaachila market. The vegetal supply was acquired, herborized and identified by through dichotomous keys. There were determined the proximal composition, phenolic compounds, flavonoids, antioxidant capacity and mineral content of the floral structures of two quelites' types. The statistical analysis was performed through a one-way analysis of variance (ANOVA) of Tukey HSD.

Results. In two sampled markets, 23 species belonging to 11 botanical families were registered, from which leaves, branches, stems, flowers and fruits are eaten. The flowers of the species Diphysa americana (Q1) and Phaseolus coccineus (Q2) are the most used for human consumption of the communities involved in the sale of the sampled quelites. Both flowers had important amounts of proteins (2.66$3.29 \%)$ and fiber (1.66-2.43\%). Q1 had higher content of phenols and flavonoids and therefore higher antioxidant capacity than Q2 $(p<0.05)$. When we talk about Q2 minerals, it presented a greater amount of $\mathrm{Zn}, \mathrm{Ca}$ and $\mathrm{Mg}$ in comparison to Q1 
48 Conclusions. In local markets of the state of Oaxaca, a wide variety of quelites

49 are usually found, where their botanical structures, such as flowers, are widely

50 eaten. The flowers of Q1 and Q2 proved to be a rich source of proteins and

51 bioactive compounds, as well as minerals. Showing thus to be a food alternative to

52 enrich the human diet.

53

54 Keywords: Quelites, phenols, antioxidant capacity, flavonoids, minerals, local

55 markets, Diphysa americana, Phaseolus coccineus

56

57

58

59

60

61

62

63

64

65

66

67

68

69

70

71 


\section{INTRODUCTION}

Located in southern Mexico, the state of Oaxaca has a high diversity of vegetation types and a great floristic richness of more than 30,000 [1-3]. In this range of biodiversity there are sixteen ethnic groups with extensive traditional knowledge on the use and management of biotic resources. Due to its extension and complexity, it still does not have a finished and updated potential flora [4]. In Mexico, the knowledge of native flora by ethnic groups allowed, since pre-Hispanic times, the use of diverse vegetal resources. This is the case of quilitl, a word of Náhuatl origin which is translated in Spanish as quelites and it is edible tender vegetables, young plants, germ or shoots of some trees and, in some cases, edible flowers [5].

Currently, the diet pattern of a large part of the mexican population is featured by industrialized food products and the gradual reduction of traditional foods. This transition in eating behavior, with a clear trend towards the consumption of industrialized products with a high energy content, has given rise to the appearance of chronic noncommunicable diseases such as cardiovascular diseases and type 2 diabetes mellitus. However, at the same time it begins to recognition and return to the consumption of non-industrialized foods, mostly with local and / or regional identity [6-8].

In Mexico, the vegetal diversity with the potential for use includes around 5000 species from different botanical families [9], most of them are herbaceous and wild [10], with food and medicinal uses [11], mainly sold in local and regional markets of the south-southeast region. The use of a large number of vegetal species has a pre-Hispanic origin and its consumption still continues in rural communities where there is a wide variety of foods for local cuisine, which has been little studied. 
Within these foods are the quelites, from which can be used the leaves, the flower and/or the fruit. In Mexico are consumed around 500 species chosen by the local traditions of the different peoples and regions [12]. Diphysa americana (Mill) M. Sousa and Phaseolus coccineus (L.) are two types of quelites where their floral structures are consumed in the rural communities of the Valles Centrales' region of Oaxaca. Diphysa americana known as flor de gallito, guachipelín, yaga-yetzi (in Zapotec language), among other names, is a vegetal species that extends from Mexico to Panama and is a slow growing deciduous tree that reaches from 20 to $65 \mathrm{ft}$ tall [13]. Phaseolus coccineus, known as quelite, frijol de monte, ayocote, colorín, among other names, is a perennial and climbing plant of several feet long which is spread along Mesoamerica and it's a legume native of the area of the current countries of Mexico and Guatemala [14].

For centuries, edible flowers have been an integral part of human nutrition. For example, in central Europe the black elder flowers (Sambucus nigra) fried or battered are common, and the dandelion flowers boiled with sugar were used as ersatz honey. In addition, the flowers were used to decorate foods prepared for the feasts and banquets of the noble people [15]. In China and Japan, edible flowers have been eaten for thousands of years $[16,17]$.

Because quelites and their botanical structures are considered under-used plants in Mexico, it is necessary to resume their study to incorporate them into the Mexican's current feeding pattern. For this, when talking about balanced diets, a wide variety of foods is included, involving green leaves and flower structures. The content of common components such as proteins, fats and vitamins in flowers are not very different in relation to other organs of the plant such as leaves [18, 19]. It 
120 has been found that some flowers are rich in phenolic compounds and have high

121 antioxidant activity, as well as the ability to inhibit chronic diseases [20-22]. In

122 addition, the color they got is predominantly due to several chemical compounds

123 such as carotenoids and flavonoids [23]. The latter ones are correlated to their high

124 antioxidant capacity [24]. In this context, the purpose of this paper was to

125 document ethnobotanical knowledge about quelites and nutritional research of two

126 best-selling species in two traditional markets of Zaachila and Zimatlán in the

127 region of the Valles Centrales of Oaxaca. The market of Zaachila is one of the

128 most diverse of those located in the Valles Centrales' region; as well as that of

129 Zimatlán. Considering the aforementioned, these two markets were chosen in

130 Plaza Days since they are a focal point for trade within the Valley of Oaxaca.

132 METHODS

\section{Sampling area}

134 The state of Oaxaca is located at southern Mexico and is divided into 8 socio-

135 cultural regions. The study markets are located in the region of the Valles

136 Centrales where the city of Oaxaca de Juárez is located and has 121

137 municipalities. In the municipality of Zimatlán de Álvarez, on Wednesdays, the local

138 market is established on the streets, while on Thursdays it is sitted in the Villa de

139 Zaachila municipality, Figure 1.

141 Figure 1. Location map of the two sampled markets and sites involved in the sale

142 of quelites from the Valles Centrales' region, Oaxaca, Mexico. Map made by 143 Matthias Rös. 
145 The municipality of Villa de Zaachila, is located between an altitude of 1400 and $1462300 \mathrm{~m}$, between the parallels $16^{\circ} 52^{\prime}$ and $17^{\circ} 02^{\prime}$ of north latitude; the meridians $14796^{\circ} 39$ 'and $96^{\circ} 52^{\prime}$ of west longitude. The range of temperature that exists in 148 Zaachila is of $16-22^{\circ} \mathrm{C}$, a range of precipitation of $600-800 \mathrm{~mm}$ and a dry climate, 149 semi-dry-semi-warm (70.99\%), semi-warm-sub-humid with rains during summer $150(26.72 \%)$ and mild-sub-humid weather with rain during summer $(2.29 \%)$ [25]. The

151 municipality of Zimatlán de Álvarez, is located between an altitude of 1400-3100 m,

152 between the parallels $16^{\circ} 34$ 'and $16^{\circ} 57^{\prime}$ ' of north latitude; meridians $96^{\circ} 45$ 'and $15397^{\circ} 13^{\prime}$ west longitude. The temperature range that exists in Zimatlán is $12-22^{\circ} \mathrm{C}$, 154 with a range of precipitation of $600-2500 \mathrm{~mm}$ and a mild-sub-humid weather with 155 rains during summer, more humid (37.45\%), semi-warm-sub-humid with summer 156 rains, more humid (21.88\%), semi-warm-sub-humid with rain during summer, less 157 humid (16.88\%), mild-humid with abundant rainfall during summer (15.17\%), dry, 158 semi-dry-semi-warm (4.99\%) and mild-sub-humid weather with rain during 159 summer, medium moisture (3.63\%) [26].

161 Sampling in the local markets of Villa de Zaachila and Zimatlán de Álvarez

162 Every week, on Wednesdays and Thursdays' morning, the markets of Zimatlán 163 and Zaachila were visited, respectively, with the purpose of identifying all the 164 stands where the quelites are sold during the Días de Plaza in each one of them. 165 Part of the botanical structures was herborized and preserved properly labeled to 166 be stored in the Herbario OAX of the CIIDIR-IPN-Oaxaca, through the technique of 
167 Long and Chiang [27] which consists of a collection of the samples, drying, labeling

168 and identification of the species.

169 In order to know the ethnobotanical aspects of the quelite species, data was

170 obtained from interviews with sellers about the places of origin and their habitat

171 features, as well as the methods of collection, uses, ways of use and demand of

172 each species [28]. There were taken pictures of the vegetal species with their

173 original presentation in the market. In some cases, the places of origin and

174 collection of the quelites were visited, following the invitation and attention of the

175 quelites' collectors-sellers.

176 The information obtained was registered for each sample taken to be incorporated

177 into a database: scientific name, botanical family, indigenous name, name in

178 Spanish, structure used, use, way of use, origin, harvest time, geographical

179 distribution, vegetation or habitat type, origin and degree of management (grown,

180 wild, tolerated) [28]. To perform the chemical and nutritional analysis, previously

181 were selected the floral structures of the Diphysa americana and Phaseolus

182 coccineus species (Figure 2).

184 Figure 2. Diphysa americana and Phaseolus coccineus flowers (from left to right in 185 the picture) collected in the local markets of Villa de Zaachila and Zimatlán de 186 Álvarez.

\section{Nutritional analysis}


191

192

193

194

195

196

197

198

199

200

201

202

203

204

205

206

207

208

209

210

211

212

213

214

Moisture, ashes, proteins, fats, fiber, carbohydrates and energy.

For moisture, ash, fat, protein and fiber determinations were used AOAC methods 925.09, 923.03, 920.39, 954.01, 962.09, respectively (2000) [29], in triplicate for each sample of quelites. The moisture was determined by drying at $105^{\circ} \mathrm{C}$ until constant weight. The ashes of the remanent were determined by calcination at 550 ${ }^{\circ} \mathrm{C}$ for $8 \mathrm{~h}$. The nitrogen was obtained by the Kjeldahl technique and the concentration of the protein was calculated using the nitrogen factor of 6.25 . The content of fats was determined by extracting them with the petroleum ether, and the total dietary fiber was determined by the incineration by the organic state that remains by the digestion with solutions of sulfuric acid and sodium hydroxide. The carbohydrates, nitrogen-free extract (NFE), were determined by subtraction (100

less the sum of proteins, fats, moisture, ashes and dietary fiber). The total energy was based on the results of carbohydrates, proteins and fats. The conversion factors were based on the metabolizable energy and analytical methods: $16.7 \mathrm{~kJ} / \mathrm{g}$ for carbohydrates, $16.7 \mathrm{~kJ} / \mathrm{g}$ for protein and $37.7 \mathrm{~kJ} / \mathrm{g}$ for fats [30].

\section{Preparation of the extract}

Extracts of the Diphysa americana (Q1) and Phaseolus coccineus (Q2) quelites were prepared as described by Rababah et al. [31] with some modifications. About $20 \mathrm{mg}$ of dry sample were mixed in $10 \mathrm{~mL}$ of $90 \%$ methanol. Subsequently, they were sonicated for 30 minutes and then filtered using Whatman filter paper number 3. 
Quantification of phenolic compounds

218 The determination of the phenols was made according to the method using the 219 Folin-Ciocalteu reagent [32]. To the extracts of the two samples of quelites (1 mL 220 per triplicate) were added a volume of $1 \mathrm{~mL}$ of distilled water, $1 \mathrm{~mL}$ of $0.5 \%$ $221 \mathrm{Na}_{2} \mathrm{CO}_{3}$ aqueous solution (w/v) and $1.0 \mathrm{~mL}$ of Folin-Ciocalteu $2 \mathrm{~N}$ reagent diluted

22210 times in water. The samples were vortexed protected from light and allowed to 223 stand for 1 hour at $25{ }^{\circ} \mathrm{C}$. The absorbance was measured at $750 \mathrm{~nm}$ in a UV224 visible spectrophotometer (Shimadzu UV-1800). The results were compared with a 225 calibration curve $\left(r^{2}=0.9814\right)$ using gallic acid standards $(0-250 \mathrm{ppm})$. The content 226 of total phenols was determined from the equation of the curve and expressed as 227 mg of gallic acid equivalents (GAE)/g dry matter.

\section{Quantification of total flavonoids}

231 The content of total flavonoids was made according to the method described by

232 Chen et al. 2014 [33]. Extracts of the two samples of quelites (2 $\mathrm{mL}$ in triplicate) were added with a volume of $150 \mu \mathrm{L}$ of $5 \% \mathrm{NaNO}_{2}$ and allowed to stand for 5

234 minutes, then $150 \mu \mathrm{L}$ of $10 \% \mathrm{AlCl}_{3} \bullet 6 \mathrm{H}_{2} \mathrm{O}$ were added and after 6 minutes of rest 235 was added $1 \mathrm{~mL}$ of $\mathrm{NaOH}$ at $1 \mathrm{M}$. The absorbance was measured at $510 \mathrm{~nm}$ in a 236 UV-visible spectrophotometer (Shimadzu UV-1800). The results were compared 237 with a calibration curve $\left(r^{2}=0.998\right)$ using quercetin standards $(0-100 \mathrm{ppm})$. The 

257 dissolved in $10 \mathrm{~mL} \mathrm{HCl} \mathrm{20 \%} \mathrm{(v/v)} \mathrm{heated} \mathrm{for} 30 \mathrm{~min}$ at slow boiling. The clear 258 solution obtained was filled with $25 \mathrm{~mL}$ deionized water in a volumetric flask [35]. 259 Each sample was made in triplicate. For the quantification of the minerals, 260

content of total flavonoids was determined from the equation of the curve and expressed as mg of quercetin equivalents (QE)/g dry matter.

\section{Determination of antioxidant capacity}

It was used the technique of the 1,1-diphenyl-2-picrilhydrazil radical (DPPH) (Sigma, Aldrich) to determine the antioxidant activity expressed as percent inhibition, following the technique described by Matthaus [34]. $100 \mu \mathrm{L}$ of each extract were taken at 5 different concentrations $(50,25,12.5,5$ and $2.5 \mathrm{mg} / \mathrm{mL})$ and $2.9 \mathrm{~mL}$ of DPPH solution $(50 \mathrm{mg} / 100 \mathrm{~mL})$ was added to each. All reactions were carried out for 30 minutes at room temperature. The absorbance at $515 \mathrm{~nm}$ was measured against the target (without extract) in a UV-visible spectrophotometer (Shimadzu UV-1800). The antioxidant activity is expressed como $\mu \mathrm{mol}$ Eq.Trolox/mg dry matter.

\section{Determination of minerals}

Samples Q1 and Q2 were dried in an oven at $230^{\circ} \mathrm{F}$ all night long, this sample was mineralized by dry route (AOAC 923.03) at $600{ }^{\circ} \mathrm{C}$ for 24 hours. The ashes were calibration curves were constructed for each mineral (zinc, copper, iron, calcium 
261 and magnesium), according to the requirements of the atomic absorption

262 spectrophotometer GBC 932AA, equipped with an air-acetylene flame burner, and

263 empty cathode lamps for each element as source of radiation [36]. From the

264 solutions obtained for the quantification of minerals in the samples, dilutions were

265 made according to the concentrations required by the calibration curves of each

266 mineral and the readings were made in the atomic absorption spectrophotometer.

267 The target of each sample was obtained with the same treatment used for the

268 sample but without the ashes. For the determination of calcium and magnesium

269 both the samples and the standards contained $5000 \mathrm{ppm}$ of lanthanum as an

270 ionization regulator. Each reading was made in triplicate and the quantity was

271 obtained from the equation of the curve of the standards used.

272

273 Analysis of results

274

275 The data obtained were analyzed with the statistical program SPSS version 15.0

276 (SPSS Inc., Chicago, IL, USA). All determinations were made in triplicate. The

277 results were expressed as the averages \pm SD. The statistical analysis was

278 performed through a one-way analysis of variance (ANOVA) of Tukey HSD.

279

280 RESULTS

281

282 Frequency of presence of species considered quelites in the markets of Villa 283 de Zaachila and Zimatlán de Álvarez 
285 market. In the first market, 15 species of quelites belonging to 9 botanical families

286 were registered and in the market of Zaachila there were 23 species grouped in 11

287 botanical families. The quelites that are sold in these markets are consumed both

288 fresh and dried and the main edible parts are the leaves, except for the species

289 selected for the chemical-nutrimental study, where the botanical structure that is

290 eaten are the flowers (Table 1). In the two markets studied, a total of 23 species

291 were registered, 15 of which occur in both markets (Figure 3). 
292 Table 1. List of presence of quelite species in the markets of Zimatlán and Zaachila.

\begin{tabular}{|c|c|c|c|c|c|}
\hline Botanical family & Scientific name & Common name & Used part & $\mathbf{Z i}$ & $\mathrm{Za}$ \\
\hline Amaranthaceae & Amaranthus hybridus L. & quintoniles $^{(1)(2)}$ & leaves & $\mathrm{x}$ & $\mathrm{x}$ \\
\hline Amaranthaceae & Amaranthus hypochondriacus L. & $\begin{array}{c}\text { amaranth(1), amaranth leaf(2), } \\
\text { quintoni( }(2)\end{array}$ & leaves & $\mathrm{x}$ & $x$ \\
\hline Asteraceae & Bidens pilosa L. & aceitillo ${ }^{(2)}$ & leaves & & $x$ \\
\hline Amaranthaceae & Chenopodium album L. Bosc ex Moq. & quelite cenizo(2) & leaves & & $x$ \\
\hline Amaranthaceae & $\begin{array}{c}\text { Chenopodium berlandieri subsp. } \\
\text { nuttalliae (Saff.) H.D.Wilson \& Heiser }\end{array}$ & huauzontle(2) & $\begin{array}{l}\text { leaves, branches, } \\
\text { flowers, seeds }\end{array}$ & & $x$ \\
\hline Apiaceae & Coriandrum sativum $\mathrm{L}$. & coriander $^{(1)(2)}$ & leaves, stems & $\mathrm{x}$ & $\mathrm{x}$ \\
\hline Fabaceae & Crotalaria pumila Ortega & chepiles $^{(1)(2)}$ & leaves, flowers & $\mathrm{x}$ & $x$ \\
\hline Cucurbitaceae & Cucurbita maxima Duchesne & $\begin{array}{l}\text { pumpik flowers } \\
\text { guías de }^{(1)(2)} \\
\text { calabaza } \\
(1)(2)\end{array}$ & $\begin{array}{l}\text { leaves, stems, flowers, } \\
\text { fruits }\end{array}$ & $x$ & $x$ \\
\hline Cucurbitaceae & Cucurbita pepo L. & $\begin{array}{l}\text { pumpik flowers(1)(2), } \\
\text { guías de calabaza }^{(1)(2)}\end{array}$ & $\begin{array}{c}\text { leaves, stems, flowers, } \\
\text { fruits }\end{array}$ & $x$ & $x$ \\
\hline Fabaceae & Diphysa americana (Mill.) M.Sousa & $\begin{array}{c}\text { guachepi }^{(1)(2)}, \text { quelites de flores de } \\
\text { guachepil(1), flor de cuachepi( }^{(2)} \\
Y_{\text {Yaviza(2) }}^{(2)}\end{array}$ & flowers & $\mathrm{x}$ & $x$ \\
\hline Cactaceae & Disocactus speciosus (Cav.) Barthlott & flor de junco ${ }^{(2)}$ & flowers & & $x$ \\
\hline Amaranthaceae & $\begin{array}{c}\text { Dysphania ambrosioides (L.) } \\
\text { Mosyakin \& Clemants }\end{array}$ & epazote ${ }^{(1)(2)}$ & leaves, stems & $x$ & $x$ \\
\hline Asteraceae & Galinsoga parviflora Cav. & piojito $^{(2),}$, hierba de piojito(2) & $S$ & & X \\
\hline
\end{tabular}




\begin{tabular}{|c|c|c|c|c|c|}
\hline Brassicaceae & Lepidium virginicum $\mathrm{L}$. & pierna de vieja ${ }^{(2)}$ & leaves, stems & & $x$ \\
\hline Brassicaceae & Nasturtium officinale R.Br. & berros $^{(1)(2)}$ & leaves & $\mathrm{x}$ & $\mathrm{x}$ \\
\hline Piperaceae & Peperomia maculosa (L.) Hook & oreja de león $n^{(2)}$ & leaves & & $x$ \\
\hline Lauraceae & Persea americana Mill. & leave of avocado(1)(2) & leaves & $\mathrm{x}$ & $x$ \\
\hline Fabaceae & Phaseolus coccineus L. & $\begin{array}{c}\text { flor de frijolón }{ }^{(1)(2)}, \text { quelite de } \\
\text { frijolón }{ }^{(1)(2)}, \text { quelite de flor de } \\
\text { frijolón }^{(2)}\end{array}$ & flowers & $x$ & $x$ \\
\hline Piperaceae & Piper auritum Kunth. & $\begin{array}{c}\text { hoja de hierba santa(2), }{ }^{(2)} \text { santa }^{(2)}\end{array}$ & leaves & $\mathrm{x}$ & $x$ \\
\hline Asteraceae & Porophyllum tagetoides (Kunth) DC. & chepiches $^{(1)(2)}$, tepiches $^{(1)(2)}$ & leaves & $\mathrm{x}$ & $x$ \\
\hline Portulacaceae & Portulaca oleracea L. & verdolagas $^{(1)(2)}$ & leaves,stems & $x$ & $x$ \\
\hline Solanaceae & Solanum nigrum L. & hierba mora(2) & leaves & & $x$ \\
\hline Asteraceae & Tridax coronopifolia (Kunth) Hemsl. & hierba de conejo ${ }^{(1)(2)}$ & leaves & $x$ & $x$ \\
\hline
\end{tabular}

293 Markets: Zimatlán (1), Zaachila (2) 
Figure 3. Frequency of the presence of the quelite species commercialized in the

295 markets of Zaachila and Zimatlán.

297 The most sold species belong to the botanical families Fabaceae and 298 Cucurbitaceae, which corresponds to the species with the highest frequency in the 299 markets (Figure 4). The frequency of the quelites in the markets of Zaachila and 300 Zimatlán varies in the different months of the year. During most of the rainy season 301 (June, July and August) the highest number of species was registered, Crotalaria 302 pumila (chepil), Cucurbita pepo (pumpkin flower), and Dysphania ambrosioides 303 (epazote) which were present throughout the year as shown in Table 2, and where 304 are shown the species of quelites sold during 2017 in both markets.

306 Figure 4. Frequency of the botanical families present in the stands of the two 307 markets Zaachila and Zimatlán.

Table 2. Temporality of the quelites species in the markets of Zaachila and

\section{Months}

\section{Specie}

$\begin{array}{llllllllllll}1 & 2 & 3 & 4 & 5 & 6 & 7 & 8 & 9 & 10 & 11 & 12\end{array}$

Amaranthus hybridus

$$
\begin{array}{llllllllllll}
Z i & Z i & Z i & Z i & Z i & Z i & Z i & Z i & Z i & Z i & Z i & Z i
\end{array}
$$

Amaranthus

Za Za, Za, Za, Za Za Za Za Za Za


hypochondriacus $\quad \mathrm{Zi} \quad \mathrm{Zi} \quad \mathrm{Zi}$

\begin{tabular}{lllll}
\hline \multicolumn{1}{c}{ Bidens pilosa } & & Za Za \\
\hline Chenopodium album & & & & Za Za \\
\hline $\begin{array}{c}\text { Chenopodium berlandieri } \\
\text { subsp. nuttalliae }\end{array}$ & Za & Za Za Za Za Za & Za \\
\hline
\end{tabular}

Coriandrum sativum

Za, Za, Za, Za, Za, Za, Za, Za, Za, Za, Za, Za, $\begin{array}{lllllllllllll}Z i & Z i & Z i & Z i & Z i & Z i & Z i & Z i & Z i & Z i & Z i & Z i\end{array}$

Za, Za, Za, Za, Za, Za, Za, Za, Za, Za, Za, Za, Crotalaria pumila

$\begin{array}{llllllllllll}Z i & Z i & Z i & Z i & Z i & Z i & Z i & Z i & Z i & Z i & Z i & Z i\end{array}$

Za, Za, Za, Za, Za, Za, Za, Za, Za, Za, Za,

Cucurbita maxima

$\begin{array}{llllllllllll}Z i & Z i & Z i & Z i & Z i & Z i & Z i & Z i & Z i & Z i & Z i & Z i\end{array}$

Za, Za, Za, Za, Za, Za, Za, Za, Za, Za, Za, Za,

Cucurbita pepo

$$
\begin{array}{llllllllllll}
Z i & Z i & Z i & Z i & Z i & Z i & Z i & Z i & Z i & Z i & Z i & Z i
\end{array}
$$

Diphysa americana Za, Za, Za, Za,

$\begin{array}{lllllll}Z i & Z i & Z i & Z i & Z i & Z i & Z i\end{array}$

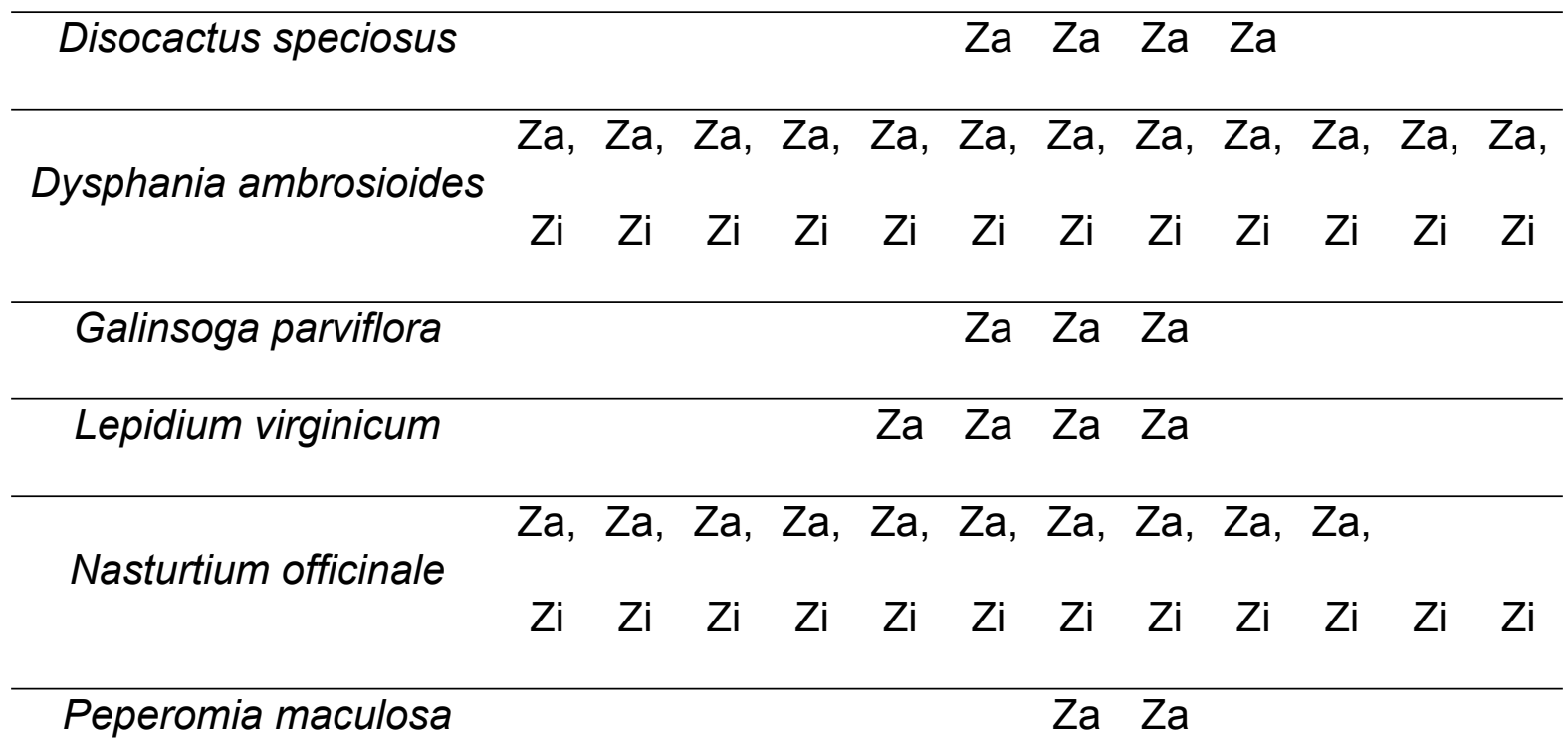


Persea americana Za Za, Za, Za, Za, Za, Za, Za Za Za, Za, Za,

$$
\text { Zi } \quad \text { Zi } \quad \text { Zi } \quad \text { Zi } \quad \text { Zi } \quad \text { Zi } \quad \text { Zi } \quad \text { Zi } \quad \text { Zi }
$$

Phaseolus coccineus Za, Za, Za, Za, Za, Za,

$$
\begin{array}{llllllllllll}
Z i & Z i & Z i & Z i & Z i & Z i & Z i & Z i & Z i & Z i & Z i & Z i
\end{array}
$$

Za, Za, Za, Za, Za, Za, Za, Za, Za,

Piper auritum

$$
\begin{array}{lllllllllll}
Z i & Z i & Z i & Z i & Z i & Z i & Z i & Z i & Z i & Z i & Z i
\end{array}
$$

Porophyllum tagetoides

$$
\text { Za, Za, Za, Za, Za, Za, Za, Za, Za, Za, Za, Za, }
$$

$$
\begin{array}{llllllllllll}
Z i & Z i & Z i & Z i & Z i & Z i & Z i & Z i & Z i & Z i & Z i & Z i
\end{array}
$$

$$
\text { Za, Za, Za, Za, Za, Za, Za, Za, }
$$

Portulaca oleracea

$$
\begin{array}{llllllllllll}
Z i & Z i & Z i & Z i & Z i & Z i & Z i & Z i & Z i & Z i & Z i & Z i
\end{array}
$$

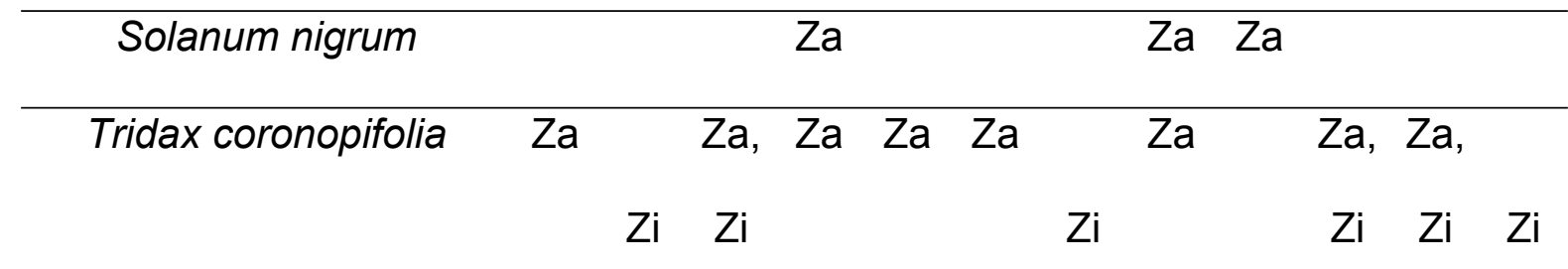

Za: Zaachila Zi: Zimatlán

\section{Nutritional study}

In Table 3, are reported the results obtained from the proximal analysis performed on the floral structures of Diphysa americana (Q1) and Phaseolus coccineus (Q2).

Table 3. Proximal composition (\%) of the quelites expressed in fresh matter

\begin{tabular}{llll}
\hline Composition & Q1 & Q2 & p \\
\hline Moisture & $87.70 \pm 0.40$ & $84.55 \pm 1.64$ & $0.032^{*}$
\end{tabular}




\begin{tabular}{lccc}
\hline Ash & $1.57 \pm 0.06$ & $1.45 \pm 0.16$ & 0.310 \\
\hline Total lipids & $0.05 \pm 0.00$ & $0.06 \pm 0.00$ & 0.116 \\
& & & \\
\hline Raw fiber & $1.66 \pm 0.06$ & $2.43 \pm 0.26$ & $0.008^{*}$ \\
\hline Proteins & $2.66 \pm 0.10$ & $3.29 \pm 0.35$ & $0.040^{*}$ \\
\hline Carbohydrates (NFE) & $6.36 \pm 0.19$ & $8.22 \pm 0.87$ & $0.023^{*}$ \\
\hline Energy (kJ/100g) & $152.9 \pm 4.8$ & $192.5 \pm 20.7$ & $0.027^{*}$ \\
\hline
\end{tabular}

Q1: Diphysa americana; Q2: Phaseolus coccineus, NFE: nitrogen-free extract.

Values are the mean \pm standard deviation of three repetitions

In relation to raw fiber, proteins, carbohydrates and energy content, the Q2 sample

322 showed higher amounts than Q1 $(p<0.05)$.

323 The results obtained for the phenolic compounds, flavonoids total and antioxidant

324 capacity are shown in Table 4 . It is observed that Q1 has a higher content of

325 phenols, flavonoids and antioxidant capacity compared to Q2 $(p<0.05)$.

327 Table 4. Phenolic compounds, flavonoids and antioxidant capacity

\begin{tabular}{llll}
\hline Composition & Q1 & Q2 & p \\
\hline Phenolic compounds & $24.6 \pm 0.67$ & $3.0 \pm 4.92$ & $0.000^{*}$ \\
(mg of GA/g of DM) & & \\
\hline Flavonoids total & $47.1 \pm 1.59$ & $4.6 \pm 0.95$ & $0.000^{*}$ \\
(mg of QE/g of DM) & & & \\
\hline Antioxidant capacity & $181.6 \pm 5.9$ & $4.7 \pm 3.3$ & $0.000^{*}$ \\
\hline
\end{tabular}


$(\mu \mathrm{mol} \quad$ Eq.Trolox/mg of

$\mathrm{Dm})$

328 GA: gallic acid; DM: dry matter; QE: quercetin equivalents; Q1: Diphysa

329 americana; Q2: Phaseolus coccineus. Values are the mean \pm standard deviation of

330 three repetitions

332 The mineral composition of the flowers studied, reported on dry basis, is given in

333 Table 5. The microelements found for Diphysa americana (Q1) and Phaseolus

334 coccineus (Q2) were zinc, copper and Iron, while the macroelements for both

335 samples were calcium and magnesium. As you can see, these edible flowers are

336 an excellent source of minerals, especially calcium and magnesium. The content of

337 these macroelements are in the range of 344.88 to $1433.91 \mathrm{mg} / 100 \mathrm{~g}$ and 47.23 to

$338146.7 \mathrm{mg} / 100 \mathrm{~g}$, respectively. Being significantly higher $(p<0.05)$ for Q2 than for

339 Q1. While zinc and copper occur in greater quantities in Q1 than in Q2.

341 Table 5. Mineral composition ( $\mathrm{mg} / 100 \mathrm{~g}$ ) of the plants on a dry basis.

\begin{tabular}{llll}
\hline Minerals & Q1 & Q2 & $\boldsymbol{p}$ \\
\hline Zinc & $4.25 \pm 0.24$ & $5.00 \pm 0.13$ & $0.009^{*}$ \\
\hline Copper & $0.99 \pm 0.05$ & $0.52 \pm 0.03$ & $0.000^{*}$ \\
\hline Iron & $10.98 \pm 0.48$ & $11.71 \pm 0.6$ & 0.196 \\
\hline Calcium & $344.88 \pm 7.19$ & $1433.91 \pm 30.22$ & $0.000^{*}$ \\
\hline Magnesium & $47.23 \pm 1.77$ & $146.70 \pm 14.70$ & $0.000^{*}$ \\
\hline
\end{tabular}


342 Q1: Diphysa americana; Q2: Phaseolus coccineus. Values are the mean \pm

343 standard deviation of three repetitions

\section{DISCUSSION}

347 Frequency of species considered quelites in the markets of Villa de Zaachila

\section{and Zimatlán de Álvarez}

349 Eight species of quelites such as aceitillo (Bidens pilosa), quelite cenizo

350 (Chenopodium album), huauzontle (Chenopodium belandieri ssp nuttalie), flor de

351 junco (Disocactus speciosus), hierba de piojito (Galinsoga parviflora), pierna de

352 vieja (Lepidium virginicum), oreja de león (Peperomia maculosa) and hierba mora

353 (Solanum nigrum), are only sold in the market of Zaachila. This richness and

354 diversity of species coincide with the information documented by Cortés Romero

355 (2005) [37]; López-Aguilar (2005) [38]; Tapia et al. (2012) [39]; Martínez-Bolaños

356 (2014) [40], who point out that in the stands outside this market there is a greater

357 influx of sellers than in other markets in the Valles Centrales' region. The people

358 who sell the quelites in these markets come from different places in the Valles

359 Centrales' region, which is divided into seven Districts, thus showing an important

360 cultural diversity. In the market of Zimatlán the quelite sellers come from three

361 Districts of the Central Valleys: 1) from the District of Zimatlán come sellers from

362 the municipalities of Zimatlán de Álvarez, San Bernardo Mixtepec, San Miguel

363 Mixtepec and Ayoquezco de Aldama; 2) of the District of Ocotlán come sellers from

364 the municipalities of Santa Lucia Ocotlan, San Antonino Castillo Velasco, San 
365

366

367

368

369

370

371

372

374

375

376 377 products of the region.

378 Cucurbita pepo is the plant with the highest frequency in these two markets,

Sebastian Teitipac and Ocotlan de Morelos; and 3) of the District of Tlacolula come only from the municipality of Tlacolula de Matamoros. In the Zaachila market, sellers come from four Districts: 1) from the Central District, mainly sellers from the municipality of Cuilapam de Guerrero and from a town in the same municipality called El Carrizal; 2) of the District of Ocotlán arrive from the municipalities of San Antonino Castillo Velasco; 3) of the District of Zimatlán arrive from the municipality of Zimatlán de Álvarez; and 4) of the District of Zaachila come from the municipalities of Santa Inés del Monte and Villa de Zaachila, as shown in Figure 1. Occasionally people arrive from the region of the Coast, as was the case of a person from the municipality Candelaria Loxicha belonging to the District of Pochutla. Observing people from different places, including a coastal municipality, supports the cultural relevance of this market in the sale of quelites and native

followed by Crotalaria pumila and Dysphania ambrosioides, probably because of the first species are also sold the stems, flowers and fruits, to cook the famous "sopa de guías", a very emblematic dish in Oaxacan cuisine; In addition, the pumpkin is grown in orchards and fields throughout the year. The quelites that are sold in these markets are eaten both fresh and dried and the main edible parts are the leaves, except for the species selected for the chemical-nutrimental study, where the botanical structure that is eaten are the flowers.

\section{Nutritional study}


388 The moisture content of the quelites studied is similar to those reported by

389 Mohammad et al. 2007 [41], which were found for Amaranthus viridis L.,

390 Chenopodium murale L., Nasturtium officinale R.Br., and Scandix pecten-veneris

391 L., a moisture range of $81.3 \%$ to $90.5 \%$. The values of the ash is similar to that

392 reported for Nasturtium officinale, (1.77\%). The protein content of the analyzed

393 samples was high for the two quelites analyzed (2.66\% for Q1 and 3.29\% for Q2).

394 The high content of raw protein in these plants can be of great importance to be

395 incorporated in the diets of marginalized communities with problems of

396 malnutrition. In addition, the fat content is very low $(<0.1 \%)$ in both samples, even

397 compared to that reported in other wild and edible plants [41], where they report

398 approximately $0.5 \%$. The raw fiber content was $1.66 \%$ for Q1 and $2.43 \%$ for Q2.

399 The World Health Organization establishes the consumption of 25 to $30 \mathrm{~g}$ of fiber

400 per day, which, although it does not contribute to the nutritional value of food, helps

401 maintain a good digestion of the organism. Therefore, the high levels of fiber

402 contained in flowers make them attractive to integrate into the diet of people. The

403 Q2 quelite sample showed the highest levels of carbohydrates (8.22\%) and

404 therefore an energy content of $192.5 \mathrm{~kJ} / 100 \mathrm{~g}$ of dry sample. According to the

405 Food Guide for the Mexican population, a serving of vegetables equals $104.6 \mathrm{kcal}$,

$4064 \mathrm{~g}$ of carbohydrates, $0 \mathrm{~g}$ of fat and $2 \mathrm{~g}$ of protein, so the equivalence of the

407 quelites would be that $50 \mathrm{~g}$ of quelites to provide between 77.4 to $96.2 \mathrm{kcal}, 3.2$ to

$4084.1 \mathrm{~g}$ of carbohydrates, $0 \mathrm{~g}$ of fats and 1.33 to $1.7 \mathrm{~g}$ of proteins.

409 By showing a relationship between phenolic compounds and the elimination of free

410 radicals, the phenolic content of plants greatly contributes to their antioxidant

411 potential [42]. In 12 species, different from those studied in this work, evaluated 
412 edible flowers found a concentration of phenolic compounds in a range of 2.53 to

$4135.28 \mathrm{mg}$ of gallic acid/g of fresh matter (26.4 to $45.7 \mathrm{mg}$ of gallic acid/g of dry

414 matter) [15]. In this sense, the Diphysa americana (Q1) quelite species is around

415 that reported in the literature. DPPH is a rapid and sensitive method to evaluate the

416 antioxidant capacity of plant extracts. This is based on the discoloration of DPPH in

417 the presence of antioxidants in the samples analyzed. According to Shahidi and

418 Wanasundara, 1992 [43] the antioxidant power is mainly due to the redox nature of

419 the phenolic compounds. Our results also confirm the aforementioned. The results

420 obtained from the total content of phenols and flavonoids total for the Q1 sample

421 also show higher activity to trap free radicals.

422 The content of the macroelements, calcium and magnesium, are in the range of

423344.88 to $1433.91 \mathrm{mg} / 100 \mathrm{~g}$ and 47.23 to $146.7 \mathrm{mg} / 100 \mathrm{~g}$, respectively. The

424 literature reports on 12 species of flowers a range of 23.9 to $49.2 \mathrm{mg} / 100 \mathrm{~g}$ of fresh

425 matter (FM) for calcium (285.6 to $425.9 \mathrm{mg} / 100 \mathrm{~g}$ of dry matter) and from 10.5 to

$42620.5 \mathrm{mg} / 100 \mathrm{~g}$ of FM for magnesium (110.0 to $212.0 \mathrm{mg} / 100 \mathrm{~g}$ of dry matter) [15].

427 This indicates that Q1 and Q2 contain more calcium but less magnesium tan

428 previously reported for 12 flowers in the literature. In the case of microelements,

429 the quantification of zinc in Q1 and Q2 $(4.25 \mathrm{mg} / 100 \mathrm{~g}$ and $5.00 \mathrm{mg} / 100 \mathrm{~g}$ of dry

430 matter, respectively) is higher than that reported for species of quelites such as

431 Nasturtium officinale but below that for Amaranthus viridis L. [41]. Zinc is a trace

432 mineral that is especially important for the normal functioning of the immune

433 system. In edible flower species such as Rosa odorata, Tropaeolum majus and

434 Tagetes patula, has been reported a concentration of 4.5 to $13.7 \mathrm{mg} / 100 \mathrm{~g}$ zinc of

435 dry matter. For flowers of the species Begonia boliviensis, Chrysanthemum 

the daily requirements would be covered with native plants of the region.

frutescens and Dianthus caryophyllus the reported iron content is in the range of 1.87 to $8.53 \mathrm{mg} / 100 \mathrm{~g}$ of dry matter, while for Centaurea cyanus, Antirrhinum majus and Dianthus caryophyllus, the content of copper has been in the range of 0.91 to $2.49 \mathrm{mg} / 100 \mathrm{~g}$ of dry matter [15]. In Table 4 it can be observed that the two species studied Diphysa americana (Q1) and Phaseolus coccineus (Q2) are well above of what was previously reported in iron. Metal ions are crucial for our body, they frequently serve as cofactors in enzymatic reactions. They are also important for the maintenance of the protein structure.

One third of the body's proteins bind to metal ions, requiring approximately $10 \%$ of the enzymes in our body zinc for its activity [44]. Zinc deficiency contributes to the death of 800,000 children worldwide per year [45]. In general, the deficiency of copper, zinc and manganese damages the cellular function, affects the development and growth, the immune system and metabolism. Copper is the main constituent of cuproproteins which are involved in energy production, iodine metabolism and metabolism of neurotransmitter synthesis [46]. Iron deficiency induces major disorders such as anemia, which affects about a third of the world's population [47]. The recommended dietary intake (RDA) in the USA is $11 \mathrm{mg} /$ day for men and 8 mg/day for zinc women; 900 ug/day of copper for both sexes and 8 $\mathrm{mg} /$ day for men and $18 \mathrm{mg} /$ day for women of iron. So when the quelites Diphysa americana and Phaseolus coccineus are properly incorporated into the human diet, 
459 The use of a large number of wild species considered quelites in the markets of the

460 Valles Centrales' region of Oaxaca has a pre-Hispanic origin and its consumption

461 still continues on a daily basis in rural and urban communities, where there is a

462 wide diversity of wild resources for local gastronomy and other ways of use. The

463 sale of quelite species is a very important activity that complements the incomes of

464 local farmers, mainly of peasant women and knowledgeable about the 465 management of agroecosystems such as family gardens, milpa and sometimes the

466 fields. You can clearly tell the difference between the retail and wholesale, the 467 latter being the one that is suggested to be more economically profitable. Both 468 markets sell different species in the wild and grown state throughout the year. 469 Regarding the chemical study of the two species of quelites have shown to be a 470 rich source of proteins and bioactive compounds. In particular, Diphysa americana

471 was the one that showed the highest content of phenolic compounds, flavonoids 472 and, therefore, greater antioxidant capacity, suggesting an alternative for future 473 research in relation to the different forms of preparation and incorporation into the 474 feeding patterns of the population. This is the first report on the chemical study 475 about of Diphysa americana and Phaseolus coccineus flowers.

\section{Bibliography}

479 1. Toledo MV. La diversidad biológica de México. Ciencia y Desarrollo. $480 \quad 1988 ; 14(81): 17-30$.

481 2. Rzedowski J. Vegetación de México. 1ra. Edición digital, Comisión Nacional 482 para el Conocimiento y Uso de la Biodiversidad, México. 2006:504. 
483 3. Miranda F, Hernández-X E. Los tipos de vegetación en México y su 484 clasificación. Edición Conmemorativa (1963-2013) ed: Sociedad Botánica de 485 México. Comisión Nacional para el Conocimiento de la Biodiversidad. Fondo de 486 Cultura Económica; 2014.

487 4. García-Mendoza AJ, Meave JA. Diversidad florística de Oaxaca: de musgos 488 a angiospermas (colecciones y lista de especies). Universidad Nacional Autónoma 489 de México-Comisión Nacional para el Conocimiento y Uso de la Biodiversidad. 490 México. 2011:352.

491 5. Linares E, Aguirre J. Los quelites, un tesoro culinario. Universidad Nacional 492 Autónoma de México. Instituto Nacional de la Nutrición "Salvador Zubirán". 493 Instituto de Biología. 1992:143.

494 6. Parrott N, Wilson N, Murdoch J. Spatializing Quality: Regional Protection 495 and the Alternative Geography of Food. European Urban and Regional Studies. $496 \quad 2002 ; 9(3): 241-61$.

497 7. González-Mendoza D, Ascencio-Martínez D, Hau Poox A, Méndez-Trujillo 498 V, Grimaldo-Juarez O, Santiaguillo-Hernández JF, et al. Phenolic compounds and 499 physicochemical analysis of Physalis ixocarpa genotypes. Scientific Research and 500 Essays. 2011;6(17):3808-14.

501 8. Bergier K, Kuzniak E, Sklodowska M. Antioxidant potential of Agrobacterium 502 transformed and non transformed Physalis ixocarpa plants grown in vitro and ex 503 vitro. Postepy Hig Med Dosw (Online). 2012;66:976-82.

504 9. Casas A, Viveros JL, Caballero J. Etnobotánica mixteca: sociedad, cultura y 505 recursos naturales en la Montaña de Guerrero, México, In: Artes. Instituto Nacional 506 Indigenista. Consejo Nacional para la Cultura y las Artes. 1994:336. 
507 10. Caballero J, Casas A, Cortés L, Mapes C. Patrones en el conocimiento, uso 508 y manejo de plantas en pueblos de México. E. Atacameños, Editor. 1998;16:1-15.

509 11. Caballero J, Rendón B, Rebollar S, Martínez MA. Uso y Manejo tradicional 510 de los Recursos Vegetales en México. In: Estudio sobre la relación entre seres 511 humanos y plantas en los albores del sigloo XXI. 2001:79-100.

512 12. Linares E, Bye R. "Naturaleza e identidad nacional", un Elogio de la Cocina

513 Mexicana, Patrimonio Cultural de la Humanidad, México: Conservatorio de la

514 Cultura Gastronómica Mexicana S.C. y Artes de México. 2012:57-67.

515 13. Flores EM, Marín WA. Diphysa americana (Mill.) M. Sousa. In: Tropical Tree 516 Seed Manual. (J. A. Vozzo, Editor). https://rngr.net/publications/ttsm. United States 517 Department of Agriculture Forest Service. 2001:439-41 pp.

518 14. Ruiz Salazar RAdldgdPcLdlsdcHdMTdMeCeB. Análisis de la diversidad 519 genética de Phaseolus cocineus L. de la subprovincia de cuarso Husteco de 520 México. Tesis de Maestría en Ciencias en Biotecnología Genómica. Centro de 521 Biotecnología Genómica, Instituto Politécnico Nacional, Reynosa, Tamaulipas. $522 \quad 2009: 65$.

523 15. Rop O, Mlcek J, Jurikova T, Neugebauerova J, Vabkova J. Edible flowers--a 524 new promising source of mineral elements in human nutrition. Molecules. $525 \quad 2012 ; 17(6): 6672-83$.

526 16. Kopec K, Balik J. Kvalitologie Zahradnickych Produktu, 1st ed.; Mendel 527 University of Agriculture and Forestry in Brno: Brno, Czech Republic2008.

528 17. Yang SL, Walters TW. Ethnobotany and the economic role of the 529 Cucurbitaceae in China. Econ Bot 1992;46:349-67. 
530 18. Upadhyay RK. Kareel plant: A natural source of medicines and nutrients. Int

531 J Green Pharm. 2011;5:255-65.

532 19. Aletor O, Oshodi AA, Ipinmoroti K. Chemical composition of common leafy

533 vegetables and functional properties of their leaf protein concentrates. . Food

534 Chem 2002;78:63-8.

535 20. Lin CC, Chung YC, Hsu CP. Potential roles of longan flower and seed 536 extracts for anti-cancer. World J Exp Med. 2012;2(4):78-85.

537 21. Hsu CL, Fang SC, Yen GC. Anti-inflammatory effects of phenolic 538 compounds isolated from the flowers of Nymphaea mexicana Zucc. Food Funct. $539 \quad 2013 ; 4(8): 1216-22$.

540 22. Besbes-Hlila M, Omri A, Ben-Jannet H, Lamari A, Aouni M, Selmi B. 541 Phenolic com- position, antioxidant and anti-acetylcholinesterase activities of the 542 tunisian scabiosa arenaria. . Pharm Biol 2013;51(5):525-32.

543 23. Friedman H, Agami O, Vinokur Y, Droby S, Cohen L, Refaeli G, et al. 544 Characterization of yield, sensitivity to Botrytis cinerea and antioxidant content of 545 several rose species suitable for edible flowers. Sci Hortic 2010;123:395-401.

546 24. Mato M, Onazaki T, Ozeki Y, Higeta D, Itoh Y, Yoshimoto Y, et al. Flavonoid 547 biosynthesis in white flowered sim carnations (Dianthus caryophyllus). Sci Hortic $548 \quad 2000 ; 84: 333-47$.

549 25. INEGI. Prontuario de información geográfica municipal de los Estados

550 Unidos Mexicanos. Villa de Zaachila, Oaxaca. Clave geoestadística 20565. 2005.

551 26. INEGI. Prontuario de información geodráfica municipal de los Estados

552 Unidos Mexicanos. Zimatlán de Álvarez, Oaxaca. Clave geoestadística 20570. 5532005. 
554 27. Lot A, Chiang F. Manual de herbario. Administración y manejo de

555 colecciones, técnicas, recolección y preparación de ejemplares botánicos. Consejo

556 Nacional de la Flora de México, A.C. IBUNAM. 1990:142.

557 28. Manzanero-Medina GI, Flores-Martínez E, Sandoval Z, Bye R. Etnobotánica 558 de siete raíces medicinales en el Mercado de Sonora de la Ciudad de México.

559 Polibotánica. 2009(27):191-228.

560 29. AOAC OMoA. Gaithersburg, Maryland, USA, AOAC International. 17 th 561 ed2000.

562 30. FAO. Food and Nutrition paper. Food energy-methods of analysis and 563 conversion factors. RomeDecember 2001.

564 31. Rababah TM, Hettiarachchy NS, Horax R. Total phenolics and antioxidant 565 activities of fenugreek, green tea, black tea, grape seed, ginger, rosemary, gotu 566 kola, and ginkgo extracts, vitamin E, and tert-butylhydroquinone. J Agric Food 567 Chem. 2004;52(16):5183-6.

568 32. Singleton VL, Rossi JA. Colorimetry of total phenolics with 569 phosphomolybdic-phosphotungstic acid reagents. . American Journal of Enology 570 and Viticulture. 1965;16:144-58.

571 33. Chen L, Xin X, Yuan Q, Su D, Liu W. Phytochemical properties and 572 antioxidant capacities of various colored berries. Journal of the Science of Food 573 and Agriculture. 2014;94(2):180-8.

574 34. Matthaus B. Antioxidant activity of extracts obtained from residues of 575 different oilseeds. J Agric Food Chem. 2002;50(12):3444-52.

576 35. Dürust N, Sumengen D. Ascorbic acid and element contents of foods of 577 Trabzon (Turkey). . Journal of Agricultural Food Chemistry. 1997;45(6):2085-7. 
578 36. Julián-Loaeza AP, Santos-Sánchez NF, Valadez-Blanco R, Sánchez-

579 Guzmán BS, Salas-Coronado R. Chemical composition, color, and antioxidant 580 activity of three varieties of Annona diversifolia Safford fruits. . Industrial Crops and

581 Products. 2011;34:1262-8.

582 37. Cortés-Romero O. Análisis comparativo de la diversidad de especies 583 suculentas en mercados de los Valles Centrales de Oaxaca. Memoria de 584 Residencia Profesional, México: Instituto Tecnológico del Valle de Oaxaca. $585 \quad 2005: 128$.

586 38. López-Aguilar P. . Diversidad y uso de las plantas silvestres en los 587 mercados del Valle de Oaxaca. Memoria de Residencia Profesional Licenciatura 588 en Biología. Instituto Tecnológico Agropecuario de Oaxaca. 2005:66.

589 39. Tapia PD, Manzanero-Medina GI, Flores MA. Etnobotánica de plantas 590 silvestres en mercados tradicionales. Región de Valles Centrales, Oaxaca, México. 591 Editorial Académica Española. . 2012:73.

592 40. Martínez-Bolaños KA. El valor de uso de las plantas ornamentales-rituales 593 comercializadas en los mercados de los Valles Centrales del estado de Oaxaca. 594 Maestría en Ciencias en Conservación y Aprovechamiento de Recursos Naturales. 595 CIIDIR-IPN-Oaxaca. . 2014:49.

596 41. Mohammad I, Farah NT, Muhammad IJ, Asifullah K, Ikhtiar K. Analysis of 597 Nutritional Components of Some Wild Edible Plants. Jour Chem Soc Pak. 2007.

598 42. Zovko Koncic M, Kremer D, Karlovic K, Kosalec I. Evaluation of antioxidant 599 activities and phenolic content of Berberis vulgaris L. and Berberis croatica Horvat. 600 Food Chem Toxicol. 2010;48(8-9):2176-80. 
601 43. Shahidi F, Wanasundara PK. Phenolic antioxidants. Crit Rev Food Sci Nutr. $6021992 ; 32(1): 67-103$.

603 44. Azia A, Levy R, Unger R, Edelman M, Sobolev V. Genome-wide 604 computational determination of the human metalloproteome. Proteins. $605 \quad 2015 ; 83(5): 931-9$.

606 45. Hagan LL, Nti C, G.M M, Danquah A. Men's Involvement in Caregivers' 607 Participation in ENAM Project Micro-credit Programme and Children's Animal 608 Source Food Consumption in Rural Ghana. Research Brief 10-04-ENAM. Global 609 Livestock Collaborative Research Support Program (GL-CRSP). University of 610 California-Davis, Davis, CA. 2010.

611 46. Mejia-Rodriguez F, Shamah-Levy T, Villalpando S, Garcia-Guerra A, 612 Mendez-Gomez Humaran I. Iron, zinc, copper and magnesium deficiencies in 613 Mexican adults from the National Health and Nutrition Survey 2006. Salud Publica 614 Mex. 2013;55(3):275-84.

615 47. Senesse P, Meance S, Cottet V, Faivre J, Boutron-Ruault MC. High dietary 616 iron and copper and risk of colorectal cancer: a case-control study in Burgundy, 617 France. Nutr Cancer. 2004;49(1):66-71. 


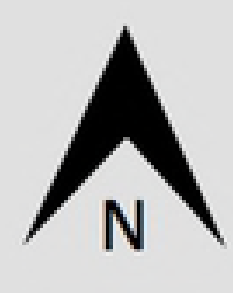

$10 \mathrm{~km}$

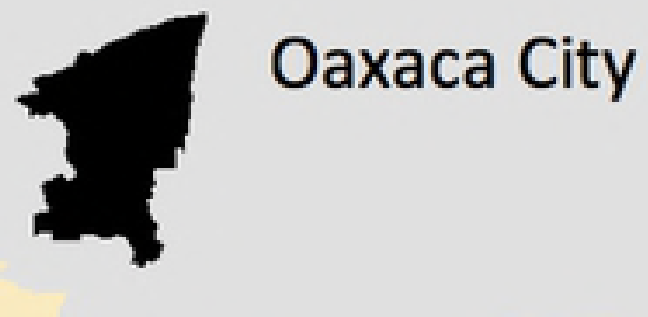

2

12 8

9

8

10

11

\section{6}

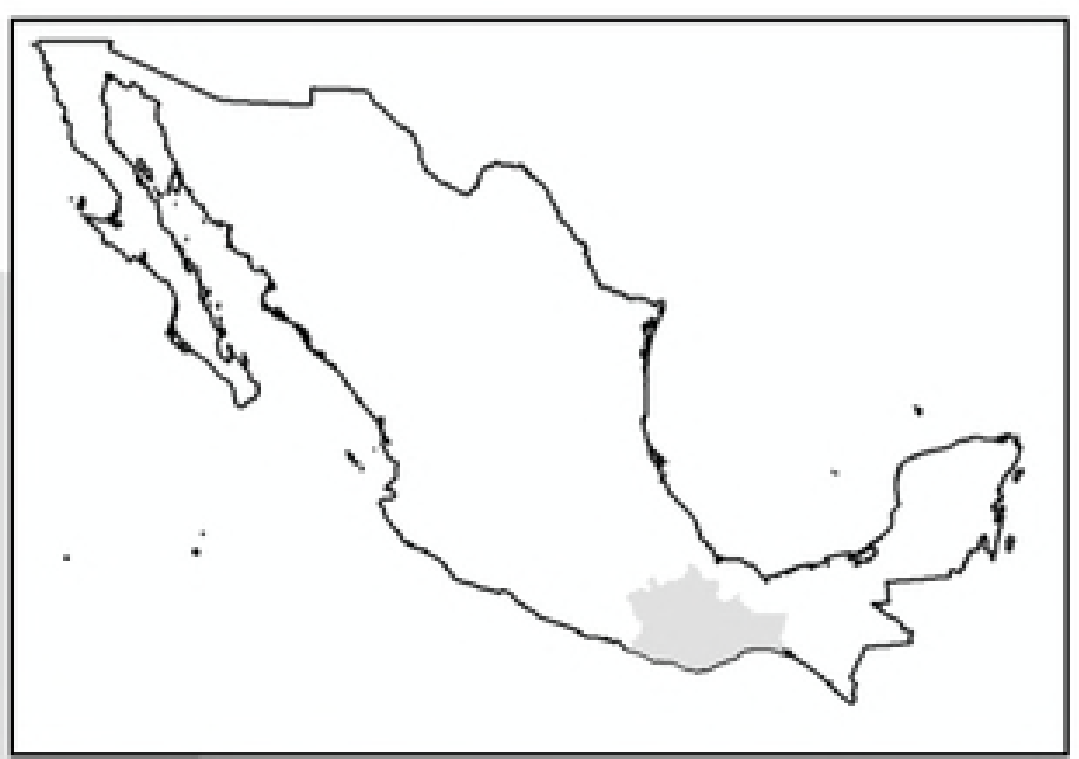

Zaachila Market

Lat $16.953966^{\circ}$, Long $-96.754330^{\circ}$

1 Villa de Zaachila

2 San Sebastian Teitipac

3 Tlacolula de Matamoros

4 San Antonino Castillo Velasco

5 Ocotlán de Morelos

6 Santa Lucia Ocotlán

7 Cuilapam de Guerrero

8 Zimatlán de Alvarez

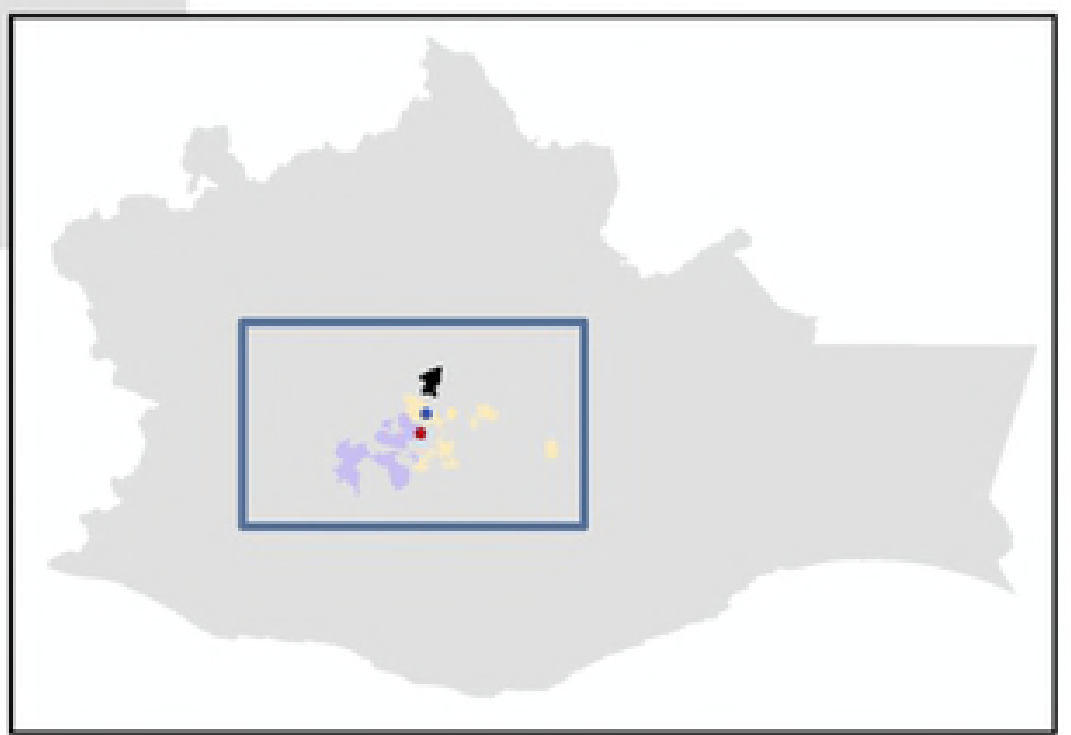

Zimatlán Market

Lat $16.867763^{\circ}$, Long $-96.784303^{\circ}$
8 Zimatlán de Alvarez 9 San Bernardo Mixtepec 10 San Miguel Mixtepec 11 Ayoquezco de Aldama 12 Santa Inés del Monte
Figure1 


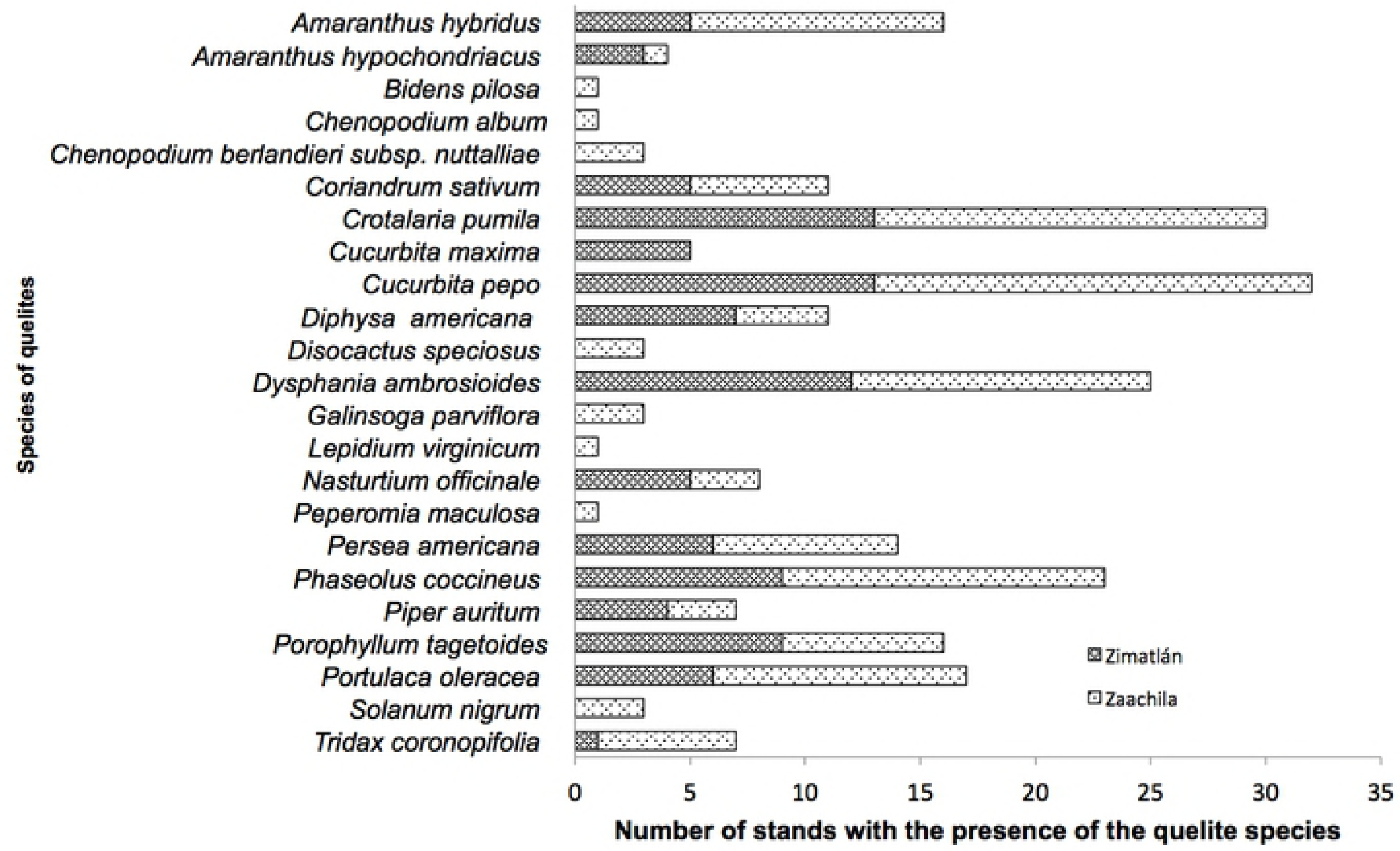

Figure3 


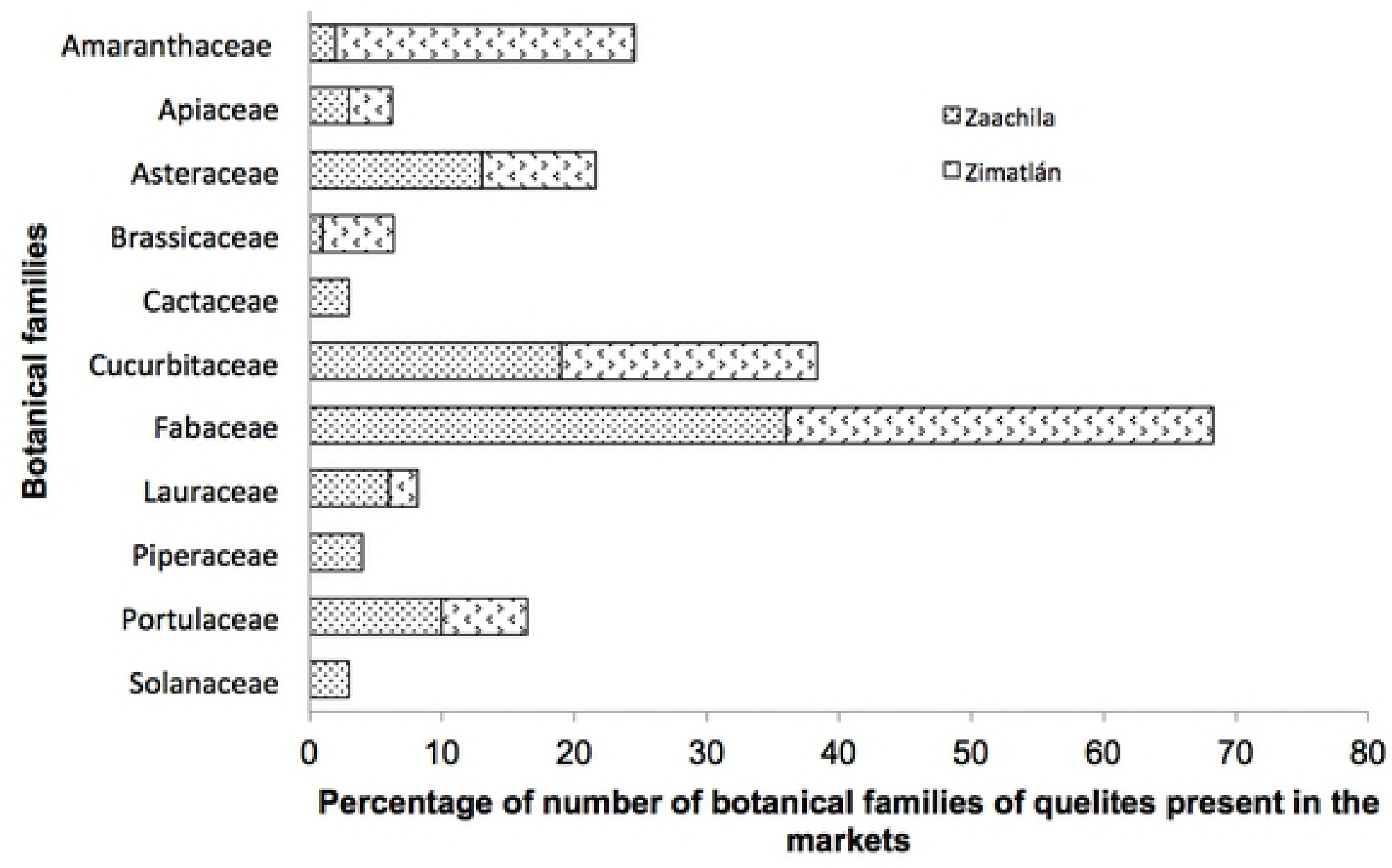

Figure4 